\title{
Population density and habitat use of the threatened Balsas screech owl in the Sierra de Huautla Biosphere Reserve, Mexico
}

\author{
Arturo Alba-Zúñiga, Paula L. Enríquez*, José Luis Rangel-Salazar \\ Departamento de Ecología y Sistemática Terrestre, El Colegio de la Frontera Sur, Apartado Postal 63-29290, \\ San Cristóbal de las Casas, Chiapas, México
}

\begin{abstract}
The Balsas screech owl Megascops seductus is a threatened species that is endemic to Mexico. We estimated the population density of the Balsas screech owl and evaluated habitat use during the dry season in the Sierra de Huautla Biosphere Reserve, Mexico. We estimated a total of 6.7 owls km $\mathrm{km}^{-2}$ during the dry season (October 2001 to April 2002) by recording spontaneous calling and responses to playback of owl calls. October showed the highest density $\left(12.2 \mathrm{owls} \mathrm{km}{ }^{-2}\right)$ and February the lowest $\left(2.8\right.$ owls $\left.\mathrm{km}^{-2}\right)$; differences between months most likely were due to calling activity rather than density. Balsas screech owls used all 5 vegetation types identified in the Sierra de Huautla Biosphere Reserve; 4 were used in proportion with their availability, and Gliricidia-Caesalpina forest was used significantly less than its availability. There was significant variation in the number of owls recorded across different vegetation types. Conserved dry forest had the highest number of owl records, followed by thorn forest, disturbed forest, agricultural systems, and the fewest records in Gliricidia-Caesalpina forest. In order to design effective conservation plans for this threatened endemic owl, future research should prioritize population trends in various parts of its range and gather life history information.
\end{abstract}

KEY WORDS: Endemic $\cdot$ Threatened species $\cdot$ Tropical owl $\cdot$ Tropical dry forest Resale or republication not permitted without written consent of the publisher

\section{INTRODUCTION}

The Balsas screech owl Megascops seductus is endemic to Mexico and has been listed as threatened by the Mexican Red List and Near Threatened globally by IUCN (Bird Life International 2008, SEMARNAT 2008). This listing is primarily due to lack of natural history information (e.g. the nests, eggs, and juveniles have not yet been described; König \& Weick 2008), its restricted range in the basin of the Balsas River in the central-west region of Mexico (Howell \& Webb 1995, del Hoyo et al. 1999), and its dependence on tropical dry forest, which is among the forest types most endangered by anthropogenic activities (Janzen 1988, Ceballos \& García 1995).

Understanding how vegetation types and habitat attributes determine the distribution and density in a population are of prime concern in terrestrial bird ecology (Janes 1985). However, habitat use is not often described for most tropical forest owls (Marcot 1995). Mexican tropical dry forest is highly diverse and rich in endemic species, with $60 \%$ of the country's endemic species occurring here (Trejo \& Dirzo 2000), and dry forests are thus considered centers of both diversification and endemism (Janzen 1988). However, they are threatened by high deforestation rates due to agriculture, grazing, and tourism development (Ceballos \& García 1995). Only $27 \%$ of tropical dry forest in Mexico is conserved; the rest experiences high deforestation rates (Trejo \& Dirzo 2000). For example, in the state of Morelos, $1.4 \%$ of dry forest has been destroyed annually for the past 3 decades (Trejo \& Dirzo 2000).

Species with restricted distributions are highly susceptible to habitat loss and fragmentation. Therefore, 
knowledge of population status and habitat requirements is essential for their effective management and conservation. Our primary goals in this study were to estimate the population density of the threatened, endemic Balsas screech owl and evaluate its habitat use during the dry season in the Sierra de Huautla Biosphere Reserve, Morelos, Mexico.

\section{MATERIALS AND METHODS}

Study species. The Balsas screech owl is relatively large (25 cm long) and heavy (150 to $175 \mathrm{~g}$ ), and is endemic to a small region in the basin of the Balsas River, Mexico, that encompasses areas in Southern Jalisco, Colima, Michoacán, central Guerrero and southern Morelos in southwestern Mexico (Howell \& Webb 1995, del Hoyo et al. 1999). Its distribution may extend to the Balsas regions in southeast Puebla (A. Alba-Zúñiga pers. obs.). It ranges in elevation from 600 to $1700 \mathrm{~m}$ above sea level, and is found exclusively in tropical dry forest in arid open and semi-open areas, including mesquite, thorn forest, columnar cacti, and second growth (del Hoyo et al. 1999, König \& Weick 2008). It feeds mainly on insects and other arthropods, although it also preys on small vertebrates (König \& Weick 2008). Aside from museum skins and accidental records, virtually no biological or ecological information is available for this species, hindering conservation efforts.

Study area. The Sierra de Huautla Biosphere Reserve is located in the southeast of the state of Morelos $\left(18^{\circ} 20^{\prime}\right.$ and $18^{\circ} 39^{\prime} \mathrm{N}_{i} 98^{\circ} 51^{\prime}$ and $\left.98^{\circ} 53^{\prime} \mathrm{W}\right)$, Mexico (Fig. 1). The protected reserve comprises 59000 ha and is the largest tract of dry forest remaining in Mexico (Argote et al. 2000). The mean annual temperature and precipitation are $24.3^{\circ} \mathrm{C}$ and $885 \mathrm{~mm}$, respectively. The highest temperatures, about $27^{\circ} \mathrm{C}$, occur in May, and the rainy season lasts from July to September (Argote et al. 2000). Most (90\%) of the vegetation in the Balsas basin is tropical dry forest that shows areas of extreme drought and includes arid areas with scattered trees and shrubs, columnar cactuses, and thorn woodlands. The forest has short trees (ca. $4 \mathrm{~m}$ ), and abundant shrubs and lianas. Almost all vegetation loses its leaves for 5 to 7 mo during the dry season (Rzedowski 1986). The remaining $10 \%$ of vegetation consists of xenophilic shrubs, aquatic vegetation, and cultivated areas (Argote et al. 2000). The dominant genera are Bursera (Burseraceae), Ceiba (Bombacaceae), Cyrtocarpa (Anacardiaceae), Lonchocarpus (Fabaceae), and Ipomea (Convolvulaceae). Columnar cacti are also abundant, including Lemaireocerus, Neobuxbaumia, Pachycereus, Stenocereus, Myrtillocactus, and Cephalocereus (Rzedowski 1986). In defor- ested areas, there are secondary associations of thorn shrubs, such as Acacia farnesiana, A. pennatula, A. cochliacantha, A. bilimekkii, Pithecellobium acatlense, Mimosa polyantha, M. benthamii, and Eysenhardtia polystachya (Rzedowski 1986).

Methodology. We estimated the density of Balsas screech owls by recording spontaneous calling and responses to playback of owl calls in line-transect distance sampling (Fuller \& Mosher 1987) during the dry season, from October 2001 to April 2002. Three 3-km transects were selected along existing trails (Santiopan, Xochipala, and Ajuchitlán; Fig. 1). Transects covered all 5 vegetation types in the reserve: conserved dry forest, perturbed dry forest, thorn forest, areas under agricultural cultivation, and Gliricidia sepium-Caesalpina pulcherrima forest.

Conserved dry forest covered $212.3 \mathrm{ha}$, approximately $39.31 \%$ of the study area. The main tree species in this ecosystem type included Bursera spp. (including B. grandifolia and B. lancifolia), Pseudomosdingium perniciosum, Amphipterigium adstringens, and Conzattia multiflora, all of which were associated with columnar cacti Lemaireocereus thurberi, Pachicereus weberi, and Mirthilocactus sp. Disturbed dry forest (126 ha, $23.33 \%$ of the study area), mainly used for cattle, consisted of patches of perturbed dry and thorn forests, dominated by Acacia cochliacantha and A. farnesiana. These patches were characterized by the presence of Gliricidia cepium and Helyocarpus venutilum, which are considered to be indicators of perturbation (Rzedowski 1986). Thorn forest (137.55 ha, $25.47 \%$ of the study area) was mainly dominated by 3 species: Acacia cochliacantha, A. farnesiana, and Leucaena sp. Agricultural areas (50.55 ha, $9.36 \%$ of the study area) were mainly planted with maize Zea mays, sorghum Sorgum vulgaris, and bean Phaseolus vulgaris. G. cepium-Caesalpina pulcherrima forest occupied $13.5 \mathrm{ha}$, or $2.5 \%$ of the study area.

All transects were surveyed an equal number of times by spontaneous calling and playback. To record spontaneous calling by owls, we walked each trail twice per month for 7 mo $(\mathrm{n}=14 \mathrm{~d})$ in suitable weather conditions. Surveys were conducted between 18:00 h and 22:00 h. All owls detected were counted and their locations triangulated by 2 people using compass bearings (Bell 1964). One person always remained at the point of the initial contact to avoid re-counting the same individual. Spot mapping allowed us to separate individuals along trails. We calculated the perpendicular distance from owl to transect after obtaining its location using the angle obtained with the compass (Bell 1964).

In order to increase detections, we also played taped vocalizations of conspecifics along roads (Fuller \& Mosher 1987). Balsas screech owl vocalizations were obtained from Hardy et al. (1990) and were played 


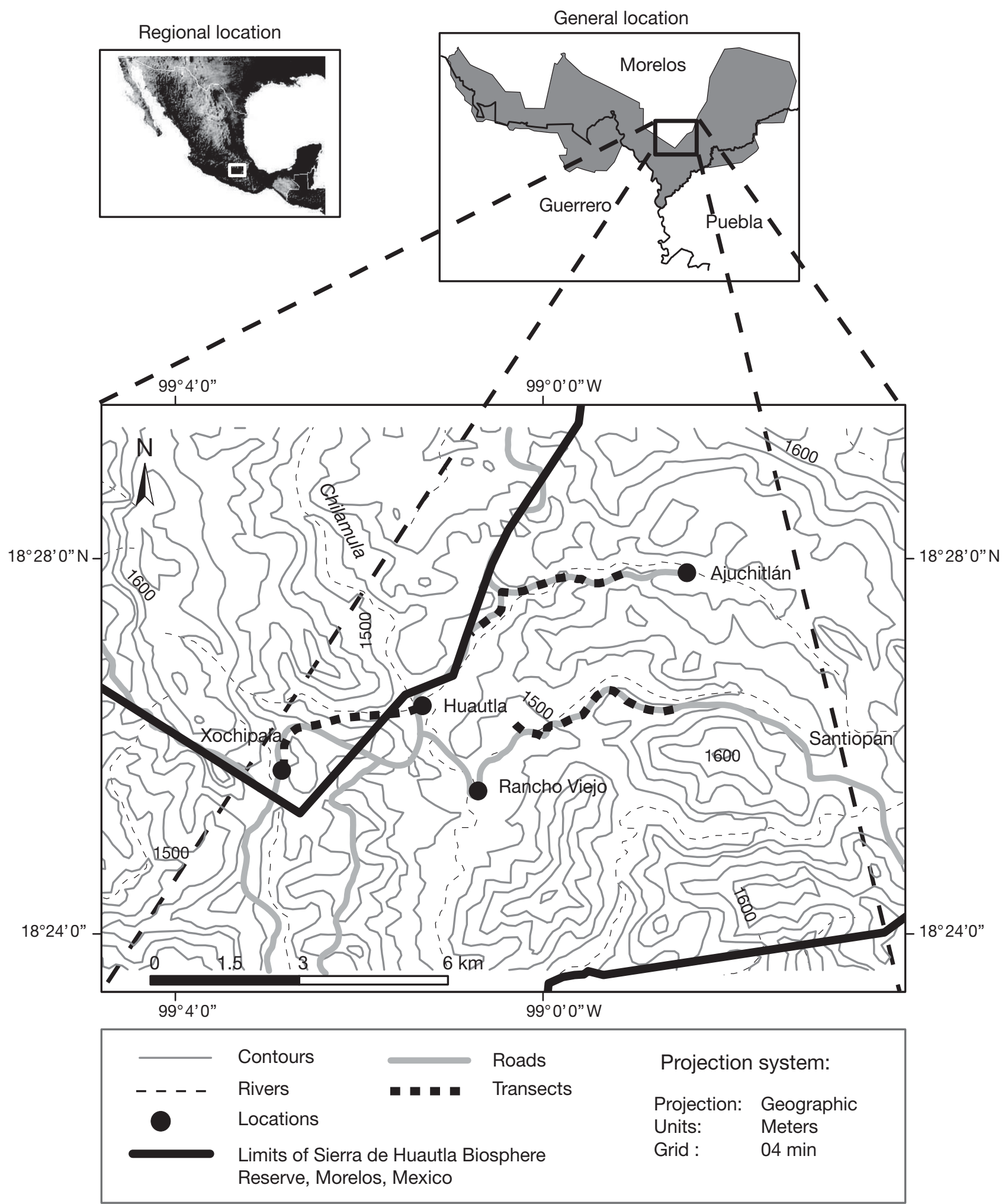

Fig. 1. Sierra de Huautla Biosphere Reserve, southeastern Morelos, Mexico. Three census transects were established along existing trails (Santiopan, Xochipala, and Ajuchitlán) 
using a tape recorder (Aiwa JS189) with 2 loudspeakers (Sony SRS-A21) at each of 36 survey points $250 \mathrm{~m}$ apart throughout the transects. We stayed at each survey point for $10 \mathrm{~min}$; the vocalization was played for $3 \mathrm{~min}$. We recorded all owls that responded to the tape.

We estimated the number of owl vocalizations per $\mathrm{km}^{2}$ using the program Distance 3.5 (Thomas et al. 1998). We were unable to determine sex or age of vocalizing owls due to the similarity of calls between sexes (König \& Weick 2008). To evaluate habitat use, we compared owl location frequencies in each vegetation type versus vegetation availability. We followed Neu et al. (1974) to estimate habitat use comparing frequencies of use and availability in each habitat type, in order to determine whether owls used habitat types in proportion to their availability. To estimate habitat use, we performed $\chi^{2}$ analysis with the program Habuse, and Bonferroni confidence limits were set at $95 \%$ to determine significance categories (Neu et al. 1974, Lund 1976). All statistical analyses were performed using JMP IN-SAS 5.1 (Sall et al. 2005). All means are presented $\pm 1 \mathrm{SD}$, and tests were considered significant at $\alpha=0.05$.

\section{RESULTS}

We recorded 279 owl vocalizations. A total of 6.7 owls $\mathrm{km}^{-2}$ was estimated in the study area during the dry season (October to April). Owl density in the highest density month (October) was significantly higher than that in the lowest month (February; 12.2 versus 2.8 owls km${ }^{-2} ; F_{6,14}=6.13, \mathrm{p}<0.05$; Fig. 2).

Balsas screech owls used all 5 vegetation types identified in the Sierra de Huautla Biosphere Reserve. Four vegetation types were used in proportion to their availability (Table 1), but the owls used the GliricidiaCaesalpina forest significantly less than its availability $\left(\chi^{2}{ }_{4}=3.96, \mathrm{p}<0.05\right)$. There were significant differences in the number of owls recorded in different vegetation types: conserved dry forest had the highest number of records, followed by thorn forest, perturbed forest, agricultural systems, and Gliricidia-Caesalpina forest $\left(F_{4,30}=4.71, \mathrm{p}<0.05\right)$.

Of the 279 total vocalizations recorded, 167 were in response to 369 playbacks (45.25\%). Although owls were more frequently recorded responding to playback $(59.9 \%)$ than calling spontaneously $(40.1 \%)$, the difference was not significant $\left(F_{1,2}=3.14, \mathrm{p}>0.05\right)$.

\section{DISCUSSION}

The total density of Balsas screech owls in the Sierra de Huautla Biosphere Reserve was estimated to be 6.7 owls $\mathrm{km}^{-2}$ during the dry season. This estimated density suggests that this species can be considered to be moderately common in the study area. Based on the frequency of vocalizations, October showed the highest Balsas screech owl density and February the lowest. In tropical areas, species density fluctuations are related mainly to seasonal variation in precipitation (Boughey 1973). Precipitation in dry forests plays a key role in determining both the vegetation structure and dynamics (Braker \& Greene 1994, Stotz et al. 1996). However, owl-calling activity may also change seasonally and with environmental conditions (Enríquez \& Rangel-Salazar 2001). The decreased response of Balsas screech owls during the dry season could be a consequence of the high seasonal variation in the dry forest, which results in a decrease in vegetative cover (Janzen 1988).

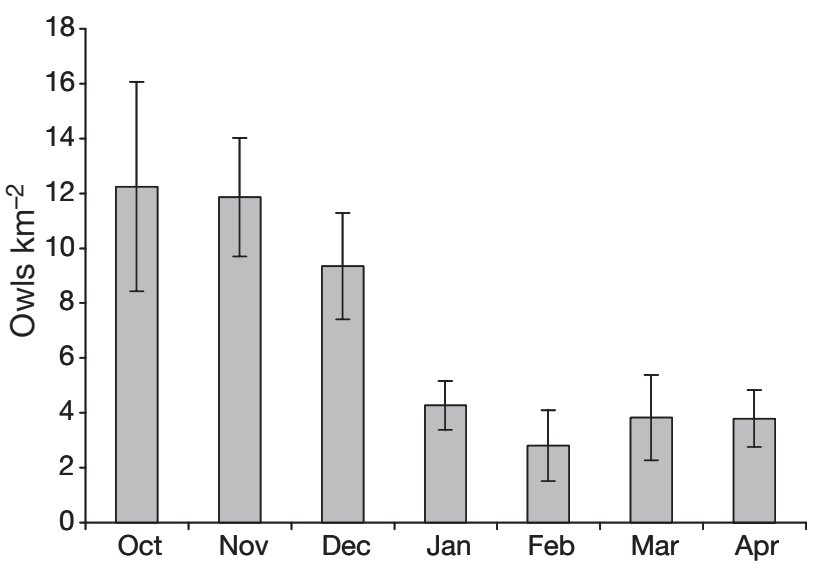

Fig. 2. Megascops seductus. Monthly mean ( \pm 1 SD) total density (owls $\mathrm{km}^{-2}$ ) in the Sierra de Huautla Biosphere Reserve (October 2001 to April 2002)

Table 1. Megascops seductus. Habitat use and availability at Sierra de Huautla Biosphere Reserve (October 2001 to April 2002). Use and availability were determined based on chi-squared analyses. Area: area of the reserve occupied by a given habitat type; Bonferroni: 95\% Bonferroni confidence limits; U=A: habitat use was equal to availability; $U<A$ : habitat was used significantly less often than predicted by availability; G. sepium-C. pulcherrinea: Gliricidia sepium-Caesalpina pulcherrima forest

\begin{tabular}{|lccccc|}
\hline Habitat type & $\begin{array}{c}\text { Area } \\
\text { (\%) }\end{array}$ & $\begin{array}{c}\text { Observed } \\
\text { (used) }\end{array}$ & $\begin{array}{c}\text { Expected } \\
\text { (availability) }\end{array}$ & $\begin{array}{c}\text { Bonferroni } \\
(\mathrm{p}<0.05)\end{array}$ & Conclusion \\
\hline Conserved dry forest & 39.31 & 0.43 & 0.39 & $0.311-0.554$ & $\mathrm{U}=\mathrm{A}$ \\
Perturbed dry forest & 23.33 & 0.18 & 0.23 & $0.093-0.285$ & $\mathrm{U}=\mathrm{A}$ \\
Thorn forest & 25.47 & 0.29 & 0.25 & $0.186-0.409$ & $\mathrm{U}=\mathrm{A}$ \\
Agrosystems & 9.36 & 0.07 & 0.093 & $0.009-0.135$ & $\mathrm{U}=\mathrm{A}$ \\
$\begin{array}{l}\text { G. sepium- } \\
\text { C. pulcherrima }\end{array}$ & 2.52 & 0.009 & 0.025 & $0.000-0.032$ & $\mathrm{U}<\mathrm{A}$ \\
\hline
\end{tabular}


Decreased response could also be related to the reproductive period of this species. The detectability of owls changes during the breeding season because reproductive adults may be either more responsive or more secretive (Fuller \& Mosher 1987). For example, density estimates of eastern screech owls Megascops asio increase at the end of the breeding season as juveniles are added to the population as independent individuals (Smith et al. 1987, del Hoyo et al. 1999). However, other studies have reported that detectability of owls increases during the courtship period (e.g. Lynch \& Smith 1984).

Balsas screech owls begin laying eggs in June (del Hoyo et al. 1999), so the maximum density estimates reported in October (12.2 ind. $\mathrm{km}^{-2}$ ) and November (11.9 ind $\mathrm{km}^{-2}$ ) may be a result of vocalizations by recently independent juveniles (Smith et al. 1987). During this time, food availability is high because insects and small vertebrates increase in abundance (Ceballos 1995). Low-density estimates in February (2.8 ind. $\mathrm{km}^{-2}$ ) and April (3.8 ind. $\mathrm{km}^{-2}$ ) may be associated not only with the pre-reproductive period but also with fewer resources during the dry season. Fluctuations in owl annual density could occur in a 2-period pattern as has been reported for other bird populations: the number of individuals increases at the end of the reproductive period because the birth rate exceeds the mortality rate, and the number of individuals decreases in the non-reproductive period because the mortality rate exceeds the birth rate (Newton 1998).

The presence of Balsas screech owls was associated with forest habitat. In the present study, we classified 5 vegetation types based on tree species abundance. Balsas screech owls used 4 vegetation types (conserved dry forest, perturbed dry forest, thorn forest, and agricultural systems) as frequently as availability would predict. These results support previous studies (del Hoyo et al. 1999, König \& Weick 2008). Balsas screech owls have also been reported to use habitats bordering cultivated areas (Lockshaw 2008); however, this species is uncommon in suburban areas (A. Alba Zúñiga pers. obs.). Tolerance of perturbed areas and variation in habitat use may be favored since habitat heterogeneity can increase the diversity of food resources and perch areas needed for survival (Morris 1987).

Food availability is one of the main factors determining habitat use by several bird species (Block \& Brennan 1993), but other factors also determine habitat use. For example, occurrence of owls may be more influenced by vegetation type than by food availability per se (Janes 1985), since habitat structure is essential for protection and nesting and perching sites (Sparks et al. 1994). The dry forest provides sites for breeding and refuge for the Balsas screech owl in tree and columnar cactus holes (König \& Weick 2008), perches for foraging and calling in bare trees or on posts in pastures (Lockshaw 2008), and perches in dense areas with canopy during the rainy season (A. Alba Zúñiga pers. obs.).

The Gliricidia sepium-Caesalpina pulcherrima forest was used less than availability would predict. This is an agro-forestry system with 2 dominant species. Heterogeneity in the other habitats may increase the diversity of food resources (Block \& Brennan 1993), and could explain why the Balsas screech owls used this vegetation type less than predicted by its availability. The current state of the vegetation in the Huautla Biosphere Reserve is a consequence of human activities, including agriculture and cattle management, that have modified the original vegetation in the region. Our results help to identify areas of conservation for this threatened endemic owl. However, future research should prioritize population trends in different areas of its distribution range (in both core and peripheral areas) and gather life history information including long-term, year-round demography and habitat selection.

Acknowledgements. We thank J. Romero for providing financial support, and Mary, Nicolás, Santos, and Serafín for providing housing and logistical support. A. Morales and E. Márquez provided field assistance, D. Johnson, K. Livezey, and 2 anonymous reviewers provided helpful comments to improve this paper. E. Valencia contributed to the map. We also thank SEMARNAT for permission to access the study area, and Idea Wild for donated equipment. We appreciate the improvements in English usage made by C. Riehl through the Association of Field Ornithologists' program of editorial assistance.

\section{LITERATURE CITED}

Argote CA, Bueno HA, Ramírez JE, Pérez JE and others (2000) AICA 40. Sierra de Huautla. In: Arizmendi MC, Márquez L (eds) Áreas de importancia para la conservación de las aves en México. CONABIO, Mexico, D.F.

Bell RE (1964) A sound triangulation method for counting barred owls. Wilson Bull 76:292-294

BirdLife International (2008) Species factsheet: Megascops seductus. Available at: www.birdlife.org/datazone/species/ index $\cdot$ html? action $=$ SpcHTMDetails $\cdot \operatorname{asp} \& \operatorname{sid}=2199 \& \mathrm{~m}=0$ (accessed Oct 2008)

Block MW, Brennan LA (1993) The habitat concept in ornithology. Theory and applications. In: Power MD (ed) Current ornithology, Vol 11. Plenum Press, New York, p 35-91

Boughey SA (1973) Ecology of populations, 2nd edn. Macmillan Publishing, New York

Braker HE, Greene HW (1994) Population biology: life histories, abundance, demography and predator-prey interactions. In: McDade LA, Bawa KS, Hespenheide HA, Hartshorn GS (eds) La Selva, ecology and natural history of a neotropical rain forest. University of Chicago Press, Chicago, IL, p 244-255 
Ceballos G (1995) Vertebrate diversity, ecology and conservation in a tropical dry forest. In: Bullock HS, Mooney AH, Medina E (eds) Seasonally dry tropical forest. Cambridge University Press, Cambridge, p 195-220

Ceballos G, García A (1995) Conserving neotropical biodiversity: the role of dry forests in western Mexico. Conserv Biol 9:1349-1353

del Hoyo J, Elliot A, Sargatal J (1999) Handbook of the birds of the world. Vol 5. Barn owls to hummingbirds. Lynx Editions, Barcelona

Enríquez PL, Rangel-Salazar JL (2001) Owl occurrence and calling behavior in a tropical rain forest. J Raptor Res 35: 107-114

Fuller RM, Mosher JA (1987) Raptor survey techniques. In: Pendleton BA, Millsap GB, Cline KW, Bird DM (eds) Raptor management techniques manual. National Wildlife Federation, Washington, DC. Sci Tech Ser 10: $37-65$

Hardy JW, Coffey BB Jr, Reynard GB (1990) Voices of New World owls (Strigiformes: Tytonidae, Strigidae). ARA Records, Gainesville, FL

Howell SNG, Webb S (1995) A guide to the birds of Mexico and northern Central America. Oxford University Press, New York

Janes SW (1985) Habitat selection in raptorial birds. In: Cody ML (ed) Habitat selection in birds. Academic Press, San Diego, CA, p 159-188

Janzen HD (1988) Tropical dry forest. The most endangered major tropical ecosystem. In: Wilson EO (ed) Biodiversity. National Academy Press, Washington, DC, p 130-137

König C, Weick F (2008) Owls of the world, 2nd edn. Helm Identification Guide, London

Lockshaw D (2008) Balsas screech owl. Available at: www. owling.com/Balsas_Screech.htm (accessed Oct 2008)

Lund RE (1976) Program HABUSE. Statistical Center, Michigan State University, East Lansing, MI

Lynch PJ, Smith DG (1984) Census of eastern screech owls (Megascops asio) in urban open-space areas using taperecorded song. Am Birds 38:388-391
Marcot BG (1995) Owls of old forests of the world. USDA For Serv Gen Tech Rep PNW-343, Pacific Northwest Research Station, Portland, OR

> Morris WD (1987) Ecological scale and habitat use. Ecology 68:362-369

Neu WC, Byers CR, Peek JM (1974) A technique for analysis of utilization-availability data. J Wildl Manag 38:541-545

Newton I (1998) Population limitation in birds. Academic Press, London

Rzedowski J (1986) Vegetación de México. Ed. Limusa, Mexico D.F.

Sall J, Creighton L, Lehman A (2005) JMP start statistics, 3rd edn. SAS Institute Inc. Thompson Learning, Belmont, CA

SEMARNAT (Secretaria Medio Ambiente y Recursos Naturales) (2008) Norma Oficial Mexicana NOM-059SEMARNAT-2001. Norma Oficial Mexicana que determina las especies y subespecies de flora y fauna silvestres y acuáticas en peligro de extinción, amenazadas, raras y las sujetas a protección especial, y que establece especificaciones para su protección. Diario Oficial de la Federación. Gobierno de los Estados Unidos Mexicanos, Mexico D.F.

Smith GD, Devine A, Walsh D (1987) Censusing screech owls in southern Connecticut. In: Nero RW, Clark RJ, Knapton RJ, Hamre RH (eds) Biology and conservation of northern forest owls. USDA For Serv Gen Tech Rep RM142, p 135-143

Sparks E, Belthoff J, Ritchison G (1994) Habitat use by eastern screech owls in central Kentucky. J Field Ornithol 65:83-95

Stotz DF, Fitzpatrick JW, Parker TA, Moskovits DK (1996) Neotropical birds. Ecology and conservation. University of Chicago Press, Chicago, IL

Thomas L, Laake JL, Derry JF, Buckland ST and others (1998) Distance 3.5. Research Unit for Wildlife Population Assessment, University of St. Andrews. Available at: www. ruwpa.st-and.ac.uk/distance/

Trejo I, Dirzo R (2000) Deforestation of seasonally dry tropical forest: a national and local analysis in Mexico. Biol Conserv 94:133-142

Submitted: March 16, 2009; Accepted: September 3, 2009

Proofs received from author(s): November 24, 2009
Editorial responsibility: Lian Pin Koh,

Zurich, Switzerland 